\title{
Correction to: Review of traditional uses, botany, chemistry, pharmacology, pharmacokinetics, and toxicology of Radix Cyathulae
}

Yongliang Huang ${ }^{1,2+}$, Shanshan Wang ${ }^{2 \dagger}$, Li Liu', Wei Peng ${ }^{2}$, Jiaolong Wang ${ }^{2}$, Ying Song ${ }^{1 *}$, Qianghua Yuan', Xing Yuan ${ }^{2}$ and Chunjie $\mathrm{Wu}^{2}$

\section{Correction to: Chin Med (2019) 14:17}

https://doi.org/10.1186/s13020-019-0237-x

In the original publication of this article [1], the English official name of the affiliation 1 has been changed to "Hospital of Chengdu University of Traditional Chinese Medicine, Chengdu, 610072, China".

\section{Author details}

${ }^{1}$ Hospital of Chengdu University of Traditional Chinese Medicine, Chengdu 610072, China. ${ }^{2}$ Chengdu University of Traditional Chinese Medicine, Chengdu 610075, China.

Published online: 06 February 2020

\section{Reference}

1. Huang Y, Wang S, Liu L, Peng W, Wang J, Song Y, Yuan Q, Yuan X, Wu C. Review of traditional uses, botany, chemistry, pharmacology, pharmacokinetics, and toxicology of Radix Cyathulae. Chin Med. 2019;14(1):17. https://doi.org/10.1186/s13020-019-0237-x.

\section{Publisher's Note}

Springer Nature remains neutral with regard to jurisdictional claims in published maps and institutional affiliations.

The original article can be found online at https://doi.org/10.1186/s1302 0-019-0237-x.

\footnotetext{
*Correspondence: songying624@163.com

${ }^{\dagger}$ Yongliang Huang and Shanshan Wang contributed equally to this work

${ }^{1}$ Hospital of Chengdu University of Traditional Chinese Medicine, Chengdu 610072, China

Full list of author information is available at the end of the article
}

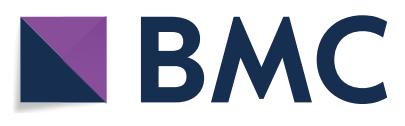

(c) The Author(s) 2020. This article is licensed under a Creative Commons Attribution 4.0 International License, which permits use, sharing, adaptation, distribution and reproduction in any medium or format, as long as you give appropriate credit to the original author(s) and the source, provide a link to the Creative Commons licence, and indicate if changes were made. The images or other third party material in this article are included in the article's Creative Commons licence, unless indicated otherwise in a credit line to the material. If material is not included in the article's Creative Commons licence and your intended use is not permitted by statutory regulation or exceeds the permitted use, you will need to obtain permission directly from the copyright holder. To view a copy of this licence, visit http://creativecommons.org/licenses/by/4.0/. The Creative Commons Public Domain Dedication waiver (http://creativecommons.org/publicdomain/zero/1.0/) applies to the data made available in this article, unless otherwise stated in a credit line to the data. 